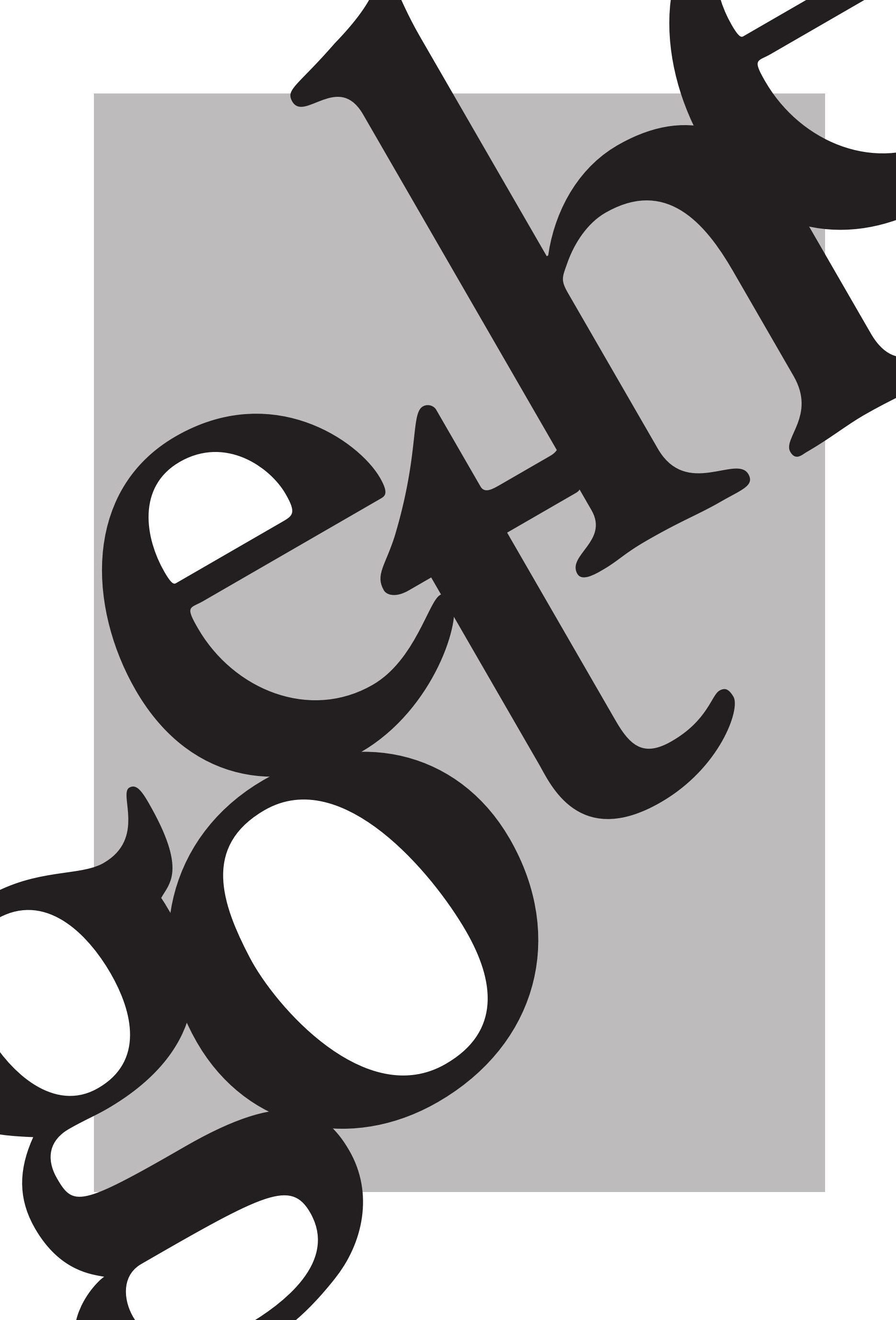




\section{O Segundo Fausto: um poema}

\section{enciclopédico-barroquizante}

\begin{abstract}
HAROLDO DE CAMPOS
é poeta, ensaísta e tradutor. É autor, entre outros, de Crisantempo (Perspectiva) e A Máquina do Mundo Repensada (Ateliê Editorial).
\end{abstract}

oethe é para os alemães o maior clássico de sua literatura." É o que escreve o ensaísta austríaco-brasileiro Otto Maria Carpeaux em A Literatura Alemã (1). A expressão "clássico", nesse contexto, deve ser entendida como "grande" ou "modelar", acrescenta o renomado estudioso.

Por outro lado, Goethe é também, reconhecidamente, um dos pioneiros do Romantismo europeu, na qualidade de figura exponencial que foi do Sturm und Drang movimento definido como "pré-romântico" nas letras alemãs. Para essa "tempestuosa" erupção do subjetivo e do passional na literatura da época, o jovem Goethe contribuiu com o romance Os Sofrimentos do Jovem Werther (Die Leiden des jungen Werther, 1774), obra que lhe rendeu sucesso internacional e duradouro. A essa fase também pertence o Primeiro Fausto, que, segundo Werner Kohlschmidt, "concentra em si quase todas as tendências essenciais do Sturm und Drang" (2). Esclareça-se que a observação de Kohlschmidt refere-se, desde logo, ao Fausto Primitivo ou Protofausto (Urfaust), escrito entre $1768 \mathrm{e}$ 1775, mas somente divulgado postumamente em 1885; constitui, porém, esse Urfaust parte essencial de Faust. Ein Fragment, dado à estampa em 1790, com modificações e acréscimos (cf. Theodor Friedrich / Lothar J. Scheithauer, Kommentar zu Goethes Faust) (3). O Primeiro Fausto propriamente dito, cuja redação final se situa entre 1797-1801, só viria à luz em 1808, sob o título Faust. Eine Tragödie. Um esquema constante da edição Goldmann-Klassiker do Faust (4) compara as versões desse Fausto (Primeira Parte/Erster Teil) cotejando as três fases aqui mencionadas e mostrando a progressiva articulação da “Tragédia de Gretchen".

Ocorre, porém, que em Weimar (onde o poeta se instalara a partir de 1776), e sobretudo depois do episódio fundamental de sua vida que foi a viagem à Itália (de 3/9/1786 a 23/4/1788, com estadas mais prolongadas em Roma), Goethe rendeu-se ao ideal grego de beleza preconizado por Joann Joachim Winckelmann em sua História da Arte da Antigüidade (Gesichte der Kunst des Altertums, 1764). Composições como as Elegias Romanas (Römische Elegien, 1788) ou a segunda versão, em poesia, à base de versos jâmbicos, de Ifigênia em Táuride (Iphigenie auf Tauris, 1786) são produtos esplêndidos da configuração desse ideal clássico-harmonioso em língua alemã.

Até aqui, parece desenhar-se um quadro bipolar, no qual podemos distinguir, 
por um lado, um Goethe romântico, vinculado ao Sturm und Drang, e, por outro, um Goethe clássico, o Goethe weimariano da maturidade e da velhice, com especial ênfase na produção dos anos que se iniciam com a viagem italiana.

Todavia, no esquema comodamente simplificador desse esboço dicotômico, interfere uma nota enigmática e dissonante. Trata-se do Segundo Fausto, completado em 1832, pouco antes da morte do octogenário Goethe. Esse Faust II (Faust. Der Tragödie. Zweiter Teil in fünf Akten) vinha sendo desenvolvido desde 1825 , ano em que o poeta retomou a sua magna tarefa (Hauptgeschäft) deixada em suspenso, à espera de uma conclusão.

Já o Primeiro Fausto, apesar de bafejar-se do clima da época do Sturm und Drang (e do emergente Romantismo), causou espécie em leitores contemporâneos da envergadura (e da erudição) do poeta e prosador Christoph Martin Wieland (17331813). Considere-se a carta de 20/6/1808, dirigida ao poeta vienense Joseph Friedrich von Retzer por Wieland, à época famoso pela autoria, entre outras obras, do poema Oberon (1780), "triunfo do rococó tardio" e, ao mesmo tempo, "pressentimento do Romantismo" (na expressão de Max Wehrli, “A Época do Iluminismo”) (5); esse poema, diga-se de passagem, foi celebrado pelo próprio Goethe. Acabara de sair o Faust. Eine Tragödie (Primeiro Fausto). Dividido entre admiração e rejeição, Wieland refere-se ao Faust. Erster Teil chamando-o de uma tragédia "barroco-genial" como "ainda não houve e jamais haverá" ("barock-genialischen Tragödie, wie noch keine war und keine jemals wieder sein wird"). Depois de ponderar, com um ressaibo de ironia, que "só o délfico Apolo poderia saber quantas outras partes ainda se seguiriam à primeira", mostra-se maliciosamente curioso em saber que sensação estaria produzindo, em Viena, “essa excêntrica obra de gênio"("dieses exzentrische Geniewerk"), em especial junto ao círculo dos admiradores do autor. Prognostica que o poema obrigará esses adeptos a "divertidas contorções" (“lustige Kontorsionen”) para impingir o Fausto como "o non plus ultra do espírito humano a mais humanodivina e diabólica de todas as obras poéticas" ("das non plus ultra des menschlichen Geistes und das göttlichist-menschlichste und teuflischste aller Dichterwerke").

Wieland chega mesmo a expressar em tom de boutade seu temor no sentido de que essa "arriscada empreitada" ("dieses Wagestück") "acabaria por fazer mais dano à reputação de Goethe do que lhe poderia causar o seu pior inimigo". E inclui para terminar uma ambígua ressalva em francês: “Vous voyez qu'à présent il n'y a qu'oser pour être sûr de réussir".

O que mais causava espécie a Wieland, no FaustoI, era justamente a Walpurgisnacht (Noite de Valpurga), "na qual nosso Musageta parece competir por levar a palma com o célebre Inferno de Bruegel em matéria de criatividade diabólica e, em matéria de obscenidade plebéia, com Aristófanes". Significativo mencionar que uma análoga reação, agora convertida em franca animadversão, iria levar Benedetto Croce, em seu livro sobre o autor do Fausto (6), a referir-se depreciativamente ao que chama "fantasia arcaizante de um Bruegel dos diabos" (aqui Croce cita Wieland), que só poderia interessar aos "comentadores alegorizantes", perquiridores de "sentidos profundos". A cena das bruxas destoaria do Fausto "poético", ou seja, aquele concebido por Goethe entre 1769 e 1775 (do Urfaust à sua expansão no Faust. Erster Teil). O outro Fausto - o da Segunda Parte e de alguns excertos arcaizantes da Primeira, entre os quais, o mais extravagante seria exatamente o sabá das feiticeiras no Monte Brocken, a tal "fantasia" obsoleta, interrompida por "frívolas alusões literárias" (sic) - responderia tão-somente a um concetto dell'intelletto. Para Croce as distorções alegóricas e as obscuridades rebuscadas eram sinais de cattivo gusto; a expressão, que em português se traduz por "mau gosto", ocorre expressamente no livro de Croce, na passagem em que o estudioso italiano censura a crítica por trataro Segundo Fausto com uma inadequada "seriedade" e, quanto à mascarada e aos cantos carnavalescos in- 
troduzidos por Goethe, tomar a atitude evasiva de "abstrair-se por trás do pretenso gran drammadell'umanità, do qual o Fausto seria o representante", pondo-se a indagar sobre o significado dessas cenas, ao invés de tomálas como aquilo que são, meros "quadrinhos satírico-morais". Pois, assevera Croce, "é coisa vã buscar no Segundo Fausto a profundidade poética”. O filósofo prossegue, aproximando Goethe de Dante e outros “poetas da alegoria": nestes casos "a profundidade é do comentário e não da poesia comentada". Visto como "poema - sistema filosófico" seria um "erro artístico" ( sic). Não à-toa Schelling teria comparado o Fausto com a Commedia...

Já o Fausto-poético ou "FaustoWerther", livre das "bizarrias da Segunda Parte", será o da "poesia verdadeira de Goethe, que tem pouca necessidade de comentário".

Em 1920, ao publicar o seu pioneiro La Poesia di Dante, Croce havia como que preparado o terreno para essas conclusões, que respondem à sua concepção idealista de poesia del cuore. Em Dante, essa maneira de pensar crociana encontra alvo crítico na metapoesia, na poesia reflexiva do Paradiso, dada como "romance teológico", artificioso, “jogo ginástico" intelectualístico e estetizante. A poesia, nesse Dante cerebral, existiria, tão-somente, "na lírica que varia e interrompe, de contínuo”, a impoética "didascália". E aqui o Fausto goethiano é chamado à colação, por recorrer também a um arcabouço "conceitual ou didascálico". Em ambos os casos, "quem tem olho e ouvido para a poesia deve sempre discernir, no curso do poema, o que é estrutural e o que é poético" (ou seja, aquilo que brote do "vital princípio lírico”, aquilo que se expressa em alemão com a palavra Gemüt). Se em Dante se podia reconhecer um libretto de esquema teológico, no Goethe do Fausto II a "forma geral" corresponderia ao libretto d'opera de um tardio "poeta de corte" (o Metastásio de Weimar). Croce evoca os fieriavversari que o Fausto II encontrou, "sobretudo na própria Alemanha, os quais chegaram mesmo ao aberto desprezo, à irrisãoe à paródia" (7). Essa recepção negativa ocorreu também em outras partes. No domínio da literatura portuguesa, Castilho, clássico da língua e tradutor peculiar (era cego e não conhecia o alemão, apoiando-se na ajuda do irmão) do Fausto I (cerca 1870), deixou expresso:

“Ao segundo Fausto, ao Fausto da velhice de Goethe, não me atrevi; seria esse um trabalho ainda mais fragoso e, quando as dificuldades se vencessem, menos acondicionado para ser bem aceito da nossa gente. Na segunda parte, dizem os alemães, é que o autor mais se despendeu em gentilezas e esmeros líricos. Pode ser; contemplado nos refletores não o parece; e depois quando essas excelências acidentais e de mera forma, rara vez traduzíveis, sejam tais como nô-las querem encarecer, tantos e tão crespos são no último Fausto os enigmas filosóficos, tão abstruso o senso das ficções, e as ficções mesmas tão desnaturais, tão inverossímeis, tão impossíveis (ia-me quase escapando, tão absurdas) que o bom gosto e o bom senso, que tão benévolos perdoaram e receberam a lenda velha do dr. Fausto, não sei como se haveriam com o Fausto último. O primeiro, o nosso, foi um gigante; o último figura-se ao espírito da nossa consciência o Homúnculo, um produto abusivo das forças da arte".

O nosso Castilho, no seu estilo de cepa vigorosa, parece compendiar, num sintético veredicto, as várias restrições que o Fausto II tem suscitado da parte de espíritos mais conservadores e menos capazes do rasgo antinormativo assumido pelo velho Goethe; sejam aqueles que se refugiam numa idéia romântico-subjetiva de lírica, sejam os que se escudam por trás de um conceito clássico de harmonia depurada e bem-ordenada.

O termo "barroco", na expressão "barroco-genial”, não traduzia, propriamente, uma precisa caracterização estilística. Esta, despida de conotações pejorativas, constitui uma aquisição da Modernidade, tendo sido Wölfflin o primeiro a atribuir valor positivo à arte do período, na qual "mesmo o próprio Burckhardt era inclinado a ver apenas um testemunho de decadência" (W.
É significativo mencionar que modernamente, R. Welleke A Warren ITeoría Literaria Madrid, Gredos, 1959|endos sam o pensador italiano: "Croce parece estar certo, ao dizer, a propósito da Segunda Parte do Fausto: 'Quando a poesia se faz superior dessa maneira, a saber, superior a si mesma, perde categoria como poesia e deve qualificar-se antes, de inferior, ou seja, de carência de poesia'". Em contrapartida, Harold Bloom (The Western Canon, New York, Riverhead Books, 1995 considera o Fausto Il um "grande elefante branco", a par do Finnegans Wake de Joyce chamando "sublime" propalado "mau gosto" de Goethe. 
Benjamin, "Ciência da Arte Rigorosa"/ "Strenge Kunstwissenschaft”) (8).

Antes, o que parece prevalecer na expressão de Wieland é a idéia de "extravagância", de "excentricidade" do Fausto, já vislumbrável na sarabanda das estregas da Primeira Parte.

Goethe é o primeiro a reconhecer as singularidades de seu poema em progresso, ao qual chama Hexenprodukt ("produto de feitiçaria") numa carta de 2/1/1799 ao editor Cotta. Em 16/9/1800, agradece a Schiller o "consolo" de lhe ter ponderado que, "da união do puro e do fantástico" na obra, poderia resultar "um monstro poético não totalmente desprezível" ("ein nicht ganzverwerfliches poetisches Ungeheuer") e chama ao poema em andamento Amalgamation. Em 6/5/1827, em conversa com Eckermann e respondendo à pergunta sobre que idéia teria buscado encarnar no Fausto, Goethe declara: "Como se eu o soubesse e pudesse expressá-lo. Do céu, pelo mundo afora, até o Inferno - isto é necessariamente algo; não é, porém, uma idéia, antes o itinerário de um agir (Gang der Handlung)"'. Depois de outras considerações, afirma: “Ademais, estou convicto de que quanto mais incomensurável for uma produção poética, quanto mais incompreensível para o entendimento, tanto melhor". Finalmente, na carta de 17/3/1832 a Wilhem von Humboldt (o poeta morreria no dia 22), Goethe refere-se ao produto dos seus longos e tenazes esforços como uma "construção estranha" ("seltsame Gebäu”), expressando o temor de que sua obra não fosse bem recebida, mas, ao invés, atirada fora como "os restos de um naufrágio" ("wie ein Wrack in Trümmern") e coberta pelas "dunas de escombros das horas" ("von dem Dünenschutt des Stunden”).

Após a revalorização, iniciada por Wölfflin, uma copiosa bibliografia vem

Gesammelte Schriften, Band III, Kritiken und Rezensionen Frankfurt a.M., Suhrkamp Verlag, 1980

9 Estudios sobre el Barroco, Madrid, Gredos, 1972

10 Manierismus in der Literatur, Hamburg, Rowohlt, 1959 ocidental, que trata de retomar a continuidade de seu próprio devir". Nesta colocação, o ponto fundamental, segundo Hatzfeld, seria a caracterização de um "estilo barroco, que assimila as aquisições do Renascimento, conservando seu substrato gótico". No caso da Espanha, ademais, “os árabes agregaram à herança latina seus floreios, suas imagens de sentido semioculto, seus enigmas e paráfrases ziguezagueantes" (e Hatzfeld lembra que Goethe dizia compreender através de Calderón os cantos do poeta persa Hafiz).

Do ponto de vista estilístico, o conceito de "clássico" por si só não dá conta da revolução estética do Fausto II. A outras elaborações teóricas se tem de recorrer para melhor compreendê-1a. Seja, ad argumentandum, a uma concepção como a de um Barroco Alto ou Clássico (Hatzfeld, para quem Tasso e Calderón serviriam neste caso de referências); seja através da bipolarização Classicismo/Maneirismo, proposta pelo discípulo de Curtius, G. R. Hocke, para quem o Barrocoé, justamente, uma forma mista, uma confluência de ambas as tendências ("Im 'Barock' berühren sich Manierismus und Klassizismus; 'Barock'ist eine Mischform von 'Manierismus' und 'Klassik', wobei der Grad der Vermengung in europäischen Landschaften und Zeiten sehr verschieden ist"); Dante, Shakespeare, Calderón, Goethe seriam exemplos dessa "concordância”, no entender de Hocke (10).

Não por acaso Goethe dá por superada a dicotomia "Clássico/Romântico" ("Es ist Zeit, das der leidenschaftliche Zwiespalt zwischen Klassikern und Romantikern sich endich versöhne"; "chegou o tempo em que a apaixonada cisão entre clássicos e românticos seja, afinal, reconciliada"; carta a Karl Jakob Ludwig Iken, 27/9/1827). Não sem propósito subtitula o episódio de Helena (publicado autonomamente em 1827 como um “interlúdio"/Zwischenspiel, mas pertencente ao Ato III do Fausto) Klassikromantisch Phantasmagorie, buscando nele fundir elementos greco-romanos com a tradição nórdico-medieval, normando-gótica (uma "síntese do nobre com o bárbaro", na 
expressãode Schiller em cartade 23/9/1800).

Goethe sentia perfeitamente que a $\mathrm{Se}$ gunda Parte, em andamento, do Fausto debordava essas categorias dadas por antinômicas e que se deixavam superar na Amalgamation fáustica que estava levando a efeito. O poeta manifesta em carta a Schiller, de 23/12/1797, sua aversão à “mescla dos gêneros"; às tendências nesse sentido chama "bizarras (de mau gosto), bárbaras, pueris" ("kindlischen, barbarischen, abgeschmackten"). Considera "alotria desarmoniosa" (carta de 28/1/1812 a Caroline von Wolzogen) a mistura de trágico e cômico em Shakespeare. Isto, como ressalta pertinentemente René Wellek, "a despeito do Segundo Fausto" (11). Cede assim, pelo menos na aparência, à preceptiva neoclássica de Schiller. Mas Goethe, polifacético, não é homem de idéias lineares. Admite que a mescla dos gêneros (por ele mesmo, aliás, praticada no último Fausto) está no horizonte dos novos tempos e-como assinala Wellek - "reconhece a inevitabilidade do processo": "Não fora a tendência romântica dos séculos não-civilizados (ungebildeter Jahrhunderte) ter feito emergir o monstruoso (das Ungeheure) em conjunção com o mau gosto bizarro (abgeschmackten), e não teríamos obras como um Hamlet, um Lear, uma La Devoción de la Cruz, um El Príncipe Constante". As duas últimas são peças de Calderón, "o poeta barroco par excellence", na opinião de H. Hatzfeld, a quem Goethe admirava em particular (a Wilhelm Schlegel devem-se "as primeiras traduções corretas de Calderón e o início da influência calderoniana sobre a poesia alemã") (12). Em Calderón, Goethe encontrou um modelo para a "tragédia do destino" ("der Schicksaltragödie"), o que o levou a acoroçoar o estudo do teatro calderoniano, "não para desculpar-lhe os condicionamentos a que estava submetido, mas para aprender a entender a maneira pela qual se libertou deles". A observação é de W. Benjamin, que define o destino como "a enteléquia no acontecer dos eventos dentro do campo da culpa" (13).

Eé o desenlace de El Mágico Prodigio- so (1637) do dramaturgo espanhol que se projeta no final do Fausto II. Ao invés de terminar com a danação do pactário, como na tradição fáustica exemplar-edificante, de que a hellish fall ("queda infernal") que conclui The Tragical History of Doctor Faustus, 1588-89, do dramaturgo isabelino Christopher Marlowe, é uma notável instância (14), na obra de Calderón o jovem signatário da avença de sangue com o Demônio é salvo. Fora movido pela hýbris do conhecimento e do poder dele resultante, que lhe asseguraria a sedução e a posse de Justina, virgem cristã modelar. Consegue redimir-se pela firmeza com que a donzela enfrenta a tentação do Maligno, exercendo, para tal, o seu “livre arbítrio" e escudada em sua fé; de sua parte, apesar de pagão, alcança um vislumbre da verdade divina num debate travado com o Adversário. "Pois o Demônio, sem sabê-lo, está fazendo ojogo de Deus" (Francisco Ruiz Ramón) (15). "Em La Devoción de la Cruz e em El Mágico Prodigioso", sublinha F. R. Ramón, "Calderón coloca o mistério da salvação eterna, mistério a cuja essência está ligada a problemática da liberdade e da verdade, juntamente com a do destino". Em Goethe, a redenção do pactário, cego e velho de um século, se dá não por arrependimento e por reconciliação com o Deus vero do cristianismo. Ao invés, oferece uma dimensão "humana, demasiado humana", como se o Céu se deixasse sensibilizar pelo incessante fazer do Fausto, à maneira da Natureza, que se obriga a imortalizar a enteléquia do homem factivo, perpetuando-a numa nova "forma de existência" ("Form des Daseins") (16). A "astúcia da graça"-que sanciona e gratifica com o seu beneplácito o ímpeto do agir inquebrantável, como se ditada por uma Sobrenatureza metamórfica, um Macrocosmo presidindo a formas em morfose - intervém então para ganhar a partida a todo custo; para ludibriar, por expedientes inclusive "excusos", de "trapaça”, o Velho Satã. Não é a graça representada por Calderón na moldura teológica da Espanha católica, embora na versão goethiana se possam encontrar elementos (antes "mágicos” do que "místicos”), do
11 História da Crítica Moderna vol. I. São Paulo, Herder/ Edusp, 1967

12 Oskar Walzel, Germa Romanticism, New York, F. Ungar Publishing Co., 1932 republicação: 1965

13 Ursprung des deutschen Trauerspiels (1925 - 1a. ed. 19281. Frankfurt a. M. Suhrkamp Verlag, 1972; Or gem do Drama Barroco Ale mão, tradução brasileira de $S$. P. Rovanet, São Paulo, Brasilense, 1984

140 Faustus de Marlowe foi ver tido para o alemão em 1818 porW. Müller. Goethe, segundo $\mathrm{H}$. Craff Robinson, que o visitou, havia pensado em traduzito, ele próprio.

15 Introdução a Pedro Calderón de la Barca, Tragedias, Madrid, Alianza Editorial 1969

16J. P. Eckermann, Gespräche mit Goethe, Berlin, Verlag von Th. Knaur Nachf., 1911 (?)); conversação datada de 4/2/ 1829 
"milagre" ou do "destino astral" (o astrales Schicksal de que fala Benjamin). Trata-se de uma graça que opera de modo subversivo, paródico, mas ainda assim - com essas rebarbas de ceticismo irônico - retraçável à "tragédia do destino" calderoniana, onde o Mal, à sua revelia, faz o jogo do Bem ...

Se pensarmos num personagem fáustico característico do Trauerspiel barroco produzido na Alemanha - e, no caso, não está em mira o teatro barroco escrito em alemão, mas aquele de matriz jesuítica, composto em latim, muito em voga no Seiscentos-impõe-se considerar o Cenodoxus sive Doctor Parisiensis (1602) de Jacob Bierdermann, "a mais importante figura no teatro alemão antes de A. Gryphius” (D. G. Dyer) (17). Cenodoxus (do verbo grego semnóo) significa o "orgulhoso", “aquele que se vangloria”. E de fato Cenodoxus, o "Doutor de Paris", célebre por sua virtude e sabedoria, morre e é condenado à danação por seu orgulho, narcisismo (filáucia) e hipocrisia; esta última o leva a pecar sem mesmo reconhecer que está pecando (o que não ocorre com o dr. Fausto de Marlowe, cujo "equilíbrio trágico" consiste "na convicção do pecado sem a crença na salvação"; Harry Levin) (18). São Bruno, fundador da Ordem dos Cartuxos, teria, segundo a lenda popular, testemunhado o cadáver de Cenodoxus erguer-se do caixão, à hora de suas exéquias, exclamando pungentemente: “Justo Dei judicio damnatus sum" ("Pelo justo juízo de Deus, eis-me condenado”). Segundo D. G. Dyer, "as cenas diabólicas da peça enchiam a audiência de terror”. Na apresentação de Cenodoxus em Munique, em 1609, foi grande o impacto sobre os espectadores, alguns dos quais se penitenciaram no ato, temerosos de sofrer a danação eterna por seus pecados. O que releva em Cenodoxus é, sempre segundo Dyer, a fusão de elementos da "comédia clássica" com a "alegoria medieval e alusões bíblicas", o que faz da peça uma "Comico-Tragoedia”, de difícil tradução por seu "latim epigramático, derivado de Sêneca”, e por seus "engenhosos calembures". Não é demais lembrar aqui o que dizia Goethe em 1817 (Schriften zur
Literatur): "Seria muito proveitoso para uma concepção mais livre do mundo, que o alemão está em vias de perder, se um jovem estudioso de talento se propusesse avaliar o verdadeiro mérito daquilo que os poetas alemães publicaram, durante três séculos, em língua latina". E Goethe declarava ter mais prazer em reler seu epos-idílico Hermann und Dorothea na versão latina do que no original alemão (19). Não é pela Grécia clássica, mas pela “Antigüidade tardia" que Goethe acaba propendendo, a ponto de, em 1815, o poeta manifestar o anelo retrospectivo de ter vivido, numa existência anterior, na época do imperador Adriano. "Sua decoração mitológico-filosófica procede sobretudo de autores tardios." Trata-se, segundo Curtius (20), de uma "Antigüidade fantasmal, reproduzida de maneira alusiva e abstrativa", que pode assumir o caráter de "compêndio" antiquarial como na Noite Clássica de Valpurga, onde "os campos de batalha de Farsália ganham o mesmo relevo que a primitiva época heróica”. Por isso, conclui Curtius, "o Segundo Fausto não entra na categoria do clássico" (e o ensaísta refere o elogio de outro estudioso, Hermann Hefele, "ao vigor e magnificência barrocos dos versos da Klassische Walpurgisnacht”). Tudo se passaria "numa intemporalidade alegórico-simbólica”, como em Calderón.

A própria escolha do cordovês Lucano (39-65 d.C.), sobrinho de Sêneca, poeta representativo da chamada "Era de Prata" da poesia latina, hoje visto como prenunciador de um "maneirismo" ibérico-romano, é um indício da propensão de Goethe acima referida. Lucano celebrizou-se como autor de um poema épico tardo-latino, antivirgiliano na concepção e anticiceroniano no estilo intrincado e rebuscado, que tem por tema a Guerra Civil entre César e Pompeu e a cruenta batalha travada nos campos da "sinistra Farsália” (dira Pharsalia, IV, 803), na Tessália, ao norte da Grécia (Homunculus descreve o cenário a Mefistófeles; Ato II, versos 6.954 e seguintes). Lucano "celebra, com particular patetismo, o herói egrégio, que faz frente ao destino" (H. Hatzfeld). O autor 


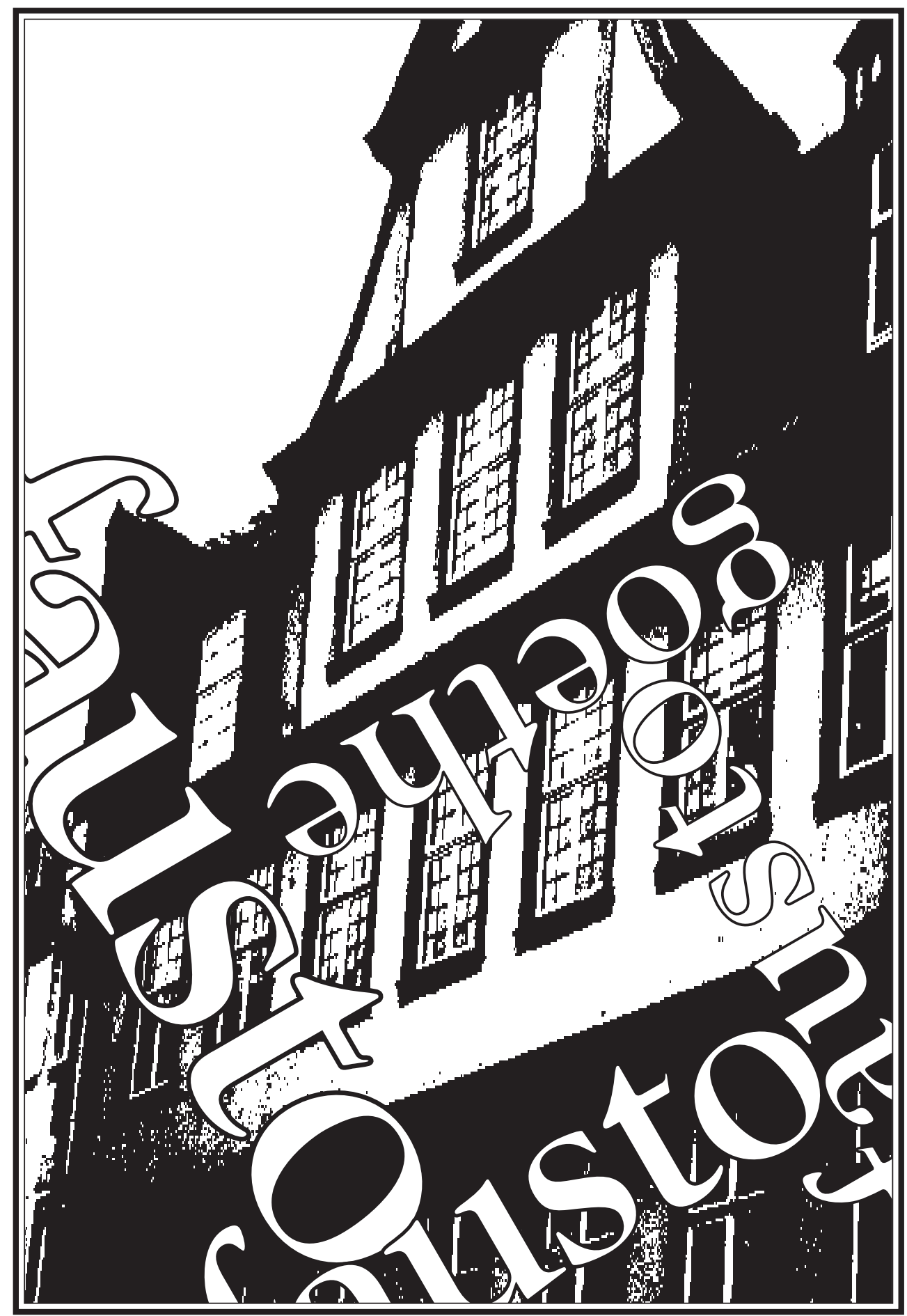

cordovês, "poeta retórico, de argumentos sofistas e alusões eruditas", hoje recuperado pelo "neogongorismo" (Carpeaux), é um dos modelos de Balthasar Gracián, o teórico do engenho e da agudeza barrocos (21). Goethe, que leu a Farsália em 1826, tomou de Lucano a figura funesta de Ericto, uma das "bruxas da Tessália" (thessalischen
Hexen, Faust II, versos 697-4), extraída do Livro VI do epos lucânico. Nesse Livro são descritos com requintes macabros os ritos ímpios da magia, levados ao excesso sacrílego pela Tessaliana, que viola sepulcros, sepulta pessoas vivas, rapina e ressuscita cadáveres. É a ela que Sextus Pompeus recorre, à véspera da batalha, para saber o
Montagem com foto de Haroldo de Campos da casa da familia Goethe em Frankfurt
21 Otto Maria Carpeaux, História da Literatura Ocidental, vol. I, Rio de Janeiro, Edições $\bigcirc$ Cru zeiro, 1959; Jean Canavaggio Historia de la Literatura Española Tomo III, El Siglo XVII, Barcelo na, Editorial Ariel, 1995 
que a sorte lhe reserva e aos seus; o filho de Pompeus Magnus roga à feiticeira que constrinja os manes a dizer a verdade (manibus exprime uerum, VI, 599). A Ericto goethiana, cuja fala abre o episódio da Noite Clássica de Valpurga (versos 7.005-40), é uma versão paródica da necrófaga megera tessaliana. Reclama dos poetas, que a teriam pintado mais "horrenda" (abscheulich) do que era de fato (os poetas aludidos são Lucano e Dante, Inferno, IX, 24: quella Eritòn cruda). E afasta-se prudentemente à aproximação dos vivos, para não causarlhes malefícios e aumentar assim sua má reputação...

Coube a Walter Benjamin, sutilíssimo teórico do Trauerspiel (Lutilúdio, Auto lutuoso) e da alegoria barroca, num artigo panorâmico sobre Goethe (1926-28, escrito logo em seguida ao Ursprung de 1923-25), pôr em relevo as vinculações do último Fausto-aquele que se costuma dar por "clássico" - com o Barroco alemão, através de cuja "representação (Vergegenwartigung) o poeta via também a Antigüidade”. Os “paços das cortes imperiais" (Kaiserhöfe) e os "palácios da Antiguiidade" (antike Paläste) são os "cenários políticos" onde se desenrola o Fausto da velhice. Na etapa derradeira de sua vida, “o poeta configura uma Alemanha ideal da época Barroca (Barockzeit), na qual enfatiza, de maneira grandiosa, todas as possibilidades do poder político, mas também põe de manifesto suas deficiências, no que têm de grotesco". A devoção à magia e à alquimia e ao esquema da transformação alegórica, paixões da era barroca e que a ela não se restringiram, “presta-se à maravilha como indicação inequívoca de qualidades barrocas em períodos posteriores". Segundo o autor do Trauerspiel, "é isso que justifica um modo de dizer mais recente, segundo o qual um gesto barroco pode ser reconhecido no Goethe tardio e no último Hoelderlin".

"A era do Barroco tem simpatias por substâncias imateriais. Artes aquáticas (Wasserkünste) e fogos de artifício (Feuerwerke) ocupam uma grande parte de sua atividade artística. Sobre a água armamse palcos. Os lagos e canais de Buen Reti- ro, Versailles e Luxemburgo [...] reanimam-se com baleias, tartarugas e Sereias canoras. Netuno aparece, puxado por corcéis marinhos, com seu séquito de Tritões, que sopram trompas de búzios" (22).

Cenários palacianos, cortejos triunfais, mascaradas, festas teatrais bizarras povoam o Fausto II. A "festa Egéia", última parte da Noite Clássica de Valpurga, é por exemplo um grande "espetáculo mítico", com desfiles e danças coreografadas sobre as ondas à luz da lua. Um espetáculo semelhante - comenta Pietro Citati (23) - foi representado no parque do palácio do Buen Retiro, em 1635, para Filipe IV de Espanha e seus convidados, tendo como objeto a primeira encenação de El Mayor Encanto, Amor, de Calderón. Na conclusão da peça, abria-se a parte posterior do palco, oferecendo-se à vista dos presentes um lago artificial, sobre o qual se desenrolava "um engenhoso espetáculo de fogo”. Galatéia, num carro triunfal exsurgia, "levada por golfinhos e escoltada por um cortejo de Tritões e de Sereias músicas". Observe-se que a nereida Galatéia também comparece, de maneira triunfal, na "Festa Egéia" (Fausto II, verso 8.154).

Seriam muitos os traços "barroquistas" ou "barroquizantes" (qualificações que prefiro usar, sempre que ocorre a pervivência do Barroco para além do seu marco histórico) discerníveis ao longo de um exame minucioso do alentado e complexo Fausto $I I$, cujo caráter de poema sincrético, suma de conhecimentos ou "enciclopédia" mitopoética, na acepção que dá ao termo Northrop Frye (24), torna desafiadora uma tarefa dessa meticulosidade.

Desde logo, porém, gostaria de pôr em evidência dois exemplos eloqüentes, por mim rastreados para ilustrar este trabalho. Através da prática da tradução criativa (Umdichtung, "transpoetização", como querem Stefan George e W. Benjamin; “transcriação", como a designo), por natureza, crítica, esses traços podem ser surpreendidos na reconfiguração do original na língua do tradutor. Em português, em matéria de Fausto, em especial o Segundo, qualquer que seja a opinião indulgente e 
obsequiosa de críticos não aparelhados para a escuta rigorosa da palavra poética em tradução, não basta (nem resolve) recorrer às versões integrais existentes, levadas a cabo por versejadores acadêmicos de segunda ordem ou pelo amadorismo de rimadores esforçados.

É notória a predileção do Barroco por jogos etimológicos (parequeses) e paronomásias. "As obras de Calderón estão cheias de formas de eco, de paronomásias e figuras etimológicas" (Hatzfeld). Muitos são os exemplos desses procedimentos que se poderiam colher no Último Fausto, nenhum mais incisivo, porém, do que "os resmungos" quase-sonoristas do Grifo "no alto Peneios". A exímia fatura dessa passagem faz lembrar, desde logo, o elogio de Goethe a esse tipo de "engenhosidade lúdica"; o poeta o considera "o mais espirituoso jogo do mundo (das witzigste Spiel von der Welt)", um jogo "que exercita o senso da língua (Sprachsinn) de maneira incrível (Moritz. als Etimolog)" (25).

GREIF schnarrend:

Nicht Greisen! Greifen! - Niemandhört Les gern.

Dass man ihn Greis nennt. Jedem Worte [klingt

Der Ursprung nach, wo es sich her

[bedingt:

Grau, grämlich, griesgram, greulich,

[Gräber, grimmig.

Etymologisch gleicherweise stimmig, Verstimmen uns.

MEPHISTOPHELES: Und doch, nicht [abzuschweifen, Gefällt das Grei im Ehrentitel Greifen.

UM GRIFO, resmungando:

Gri não de gris, grisalho, mas de Grifo! Do gris de giz, do grisalho de velho Ninguém se agrada. O som é um espelho Da origem da palavra, nela inscrito. Grave, gralha, grasso, grosso, grés, gris Concertam-se num étimo ou raiz

Rascante, que nos desconcerta.

MEFISTÓFELES: O grifo

Tem grito e garra no seu nome-título.
Focalizarei, agora, mais detalhadamente, o espisódio que abre o Fausto II (Ato I), subtitulado “Anmutige Gegend", "Sítio Aprazível”. Traduzi a expressão transpondo-a para o latim "Locus Amoenus", para evidenciar que se trata de um topos retórico: o do "lugar ameno", que remonta à poesia pastoril de Teócrito (séc. III a.C.) e percorre, a seguir, a poesia latina, a Renascença, o Maneirismo e o Barroco. É possível evocar, a título de exemplo (em aproximativo paralelo cenográfico com o episódio goethiano), aquela passagem "arcádica" da Soledad Primera de Gôngora, na qual o poeta cordovês descreve o seu personagem - um náufrago-peregrino adormecido-no ato de despertar com o nascer do sol:

“Durmió, y recuerda al fin cuando las aves, esquilas dulces de sonora pluma, señas dieron suaves

Del Alba al Sol, que el pabellón de espuma dejó, y en su carroza

rayó el verde obelisco de la choza”.

"O Fausto de Goethe é uma 'restauração de todas as coisas' [...] dentro do processo universal da literatura - e, por conseguinte, da poesia pastoril", escreve Curtius, o notável estudioso da tópica na literatura européia.

Em "Sítio Aprazível", acodem à cena Ariel, o benévolo espírito aéreo da Tempestade de Shakespeare (um autor, por sinal, "maneirista", na visão dos teóricos mais recentes), e os benfazejos elfos (do Sonho de uma Noite de Verão, do mesmo Shakespeare e do Oberon, o epos rocóco de Wieland). Vêm para o refrigério do Fausto adormecido, para lhe trazer, por meio do "orvalho do Letes", o oblívion de suas terríveis culpas, submetendo-o como que a uma "hipnoterapia" (26). A natureza é descrita com lavores de decoração barroca, do sono noturno do pecador e dos elementos até o nascer glorioso da Aurora. Goethe inspirou-se, neste passo, no afresco l'Aurora do Palazzo Rospiglioni, em Roma, executadoem 1601 por Guido Renni (15751642), pintor da Escola de Bolonha, cuja arte se caracteriza por um "temperado
25 Karl Phillip Moritz (1756-93) e Goethe discutiram questões de estética, quando da estada do poeta na ltália: cf Italienisch Reise - III, dezembro/1787

26 David Luke, "Introdução" a J. W. Goethe, Faust/Part Two Oxford/New York, Oxford University Press, 1994. 
27 Germain Bazin, Baroque and Rococo, New York/Toronto, Oxford University Press, 1964 G. E. Mottini, Storia dell'Arte Italiana, II, Verona, Arnaldo Mondadori, 1949

28 Jenny Klabin Segall Itradutora Goethe/Fausto, Belo Horizonte/ SãoPaulo, ltatiaia/Edusp, 1981 Publicação original: 1938॥| 1970(II). Agostinho D'Ornellas (tradutor), J.W. Goethe/Fausto: Coimbra, Acta Universitatis Conimbricensis, 1953. Publicação original: 1867||, 1873(II).

29 E. R. Curtius, Literatura Européia e Idade Média Latina (1953) São Paulo, Hucitec/Edusp 1996. Tradução brasileira de Teodoro Cabral e Paulo Rónai.

30 Goethe, Farbenlehre (1810) I. W. Goethe, Theory of Colours, tradução para o inglês de C. L. Eastlake, Cambridge Mass. The MIT Press, 1970; Doutrina das Cores, tradução brasileira de Marco Giannotti São Paulo, Nova Alexandria 1993. W. Benjamin, Goethe op. cit. na nota 22 barroquismo" (G. Bazin), por um "aroma de grecidade alexandrina” (G. E. Mottini) (27). O "remorso" do Fausto, por seu comportamento corruptor em relação a Gretchen, é metaforizado: o interno remorder é comparado a "glühend bittre Pfeile" ("flechas ardentes e amargas"); em minha transcriação: “áscua aguçada”. No plano fônico, busquei compensar a tríplice aliteração em "f”" (EntFernt/VorwurFss/ Pfeile) com o jogo paronomástico entre ÁSCUA e AGUÇAda. Comparativamente, são triviais as soluções “Da alma extraílhe o dardo da amargura" (Jenny Klabin Segall) e "Do seio the arrancai o remorso pungente" (Agostinho D'Ornellas) (28). O léxico e as rimas de Goethe não podem ser banalizados; seus versos não podem redundar em "platitudes", antes, exigem do tradutor criatividade, ousadia, competência artesanal. Optei pela rima assonante onde a consoante seria, em português, de pouco préstimo estético. Trabalhei com um verso heptassílabo (para os metros curtos) e um de nove sílabas (para os mais longos) do original; neste último caso, quis evitar o decassílabo, já que, em nossa tradição poética, exibe uma forte estampa épica. A transposição do "Locus Amoenus" no "Jardim do Éden" bíblico (“Paraíso", de pardés em hebraico, procedente do persa, com o significado de jardim) já ocorria na literatura latina cristã medieval (Curtius) (29). O Paraíso terrestre goethiano ("Ein Paradies wird um mich her die Runde"/ “Tenho um paraíso em meu redor") é um éden primaveril de luz e cor. Mas pode sobrevir, também, uma avassaladora torrente de chamas ("Ein Flammenübermass"/ "Um plus-de-flamas"), que causa espanto ao Fausto, sequioso embora por acender a "tocha da vida" ( "des Lebens Fackel"). Em sua perplexidade, ele não sabe se é feita de "amor ou ódio" essa torrente que parece “intercambiar alegria e dor". Procurei reconfigurar o composto goethiano em minha tradução acima transcrita, assim como, em passagem anterior, quando o poeta fala em Geistesören, recorri a uma síntese sintagmática à Sousândrade (por ex., “alma-Deus”) - “ouvido-espírito” (ou seja, escuta que procede do espírito, cuja função é espiritual) -, para manter o conciso vigor do original. "Colhe a mente ondas sonoras" (J. K. Segall) e "De espírito sente o ouvido" (D’Ornellas) são soluções poeticamente pobres; a segunda, ademais, é extraviante quanto ao significado.

Nesse “sítio ameno", paradisíaco, Goethe faz que a luz irrompa em contraste polar com a profunda escuridão, numa antítese (figura de estilo prestigiada no Maneirismo e no Barroco) que, no caso, procede da Farbenlehre (Doutrina das Cores); nesta, as cores surgem da transição do branco para o negro. Em retórica, a "antítese" é também chamada "contraponto" ou “metáfora de oposição”. W. Benjamin, no texto sobre Goethe, observa: "Newton explica a luz branca como uma composição (Zusammensetzung) de luzes coloridas; Goethe, ao contrário, como a essência mais simples, infragmentável e homogênea que conhecemos [...] A Doutrina das Cores considera-as como metamorfoses da luz, como fenômenos que se produzem na luta da luz com a escuridão. Ao lado da idéia da metamorfose é importante para Goethe a idéia da polaridade que caracteriza toda a sua pesquisa. O escuro nãoé mera ausência (Abwesenheit) de luz - caso contrário não seria perceptível - mas, sim, uma antiluz positiva (ein positives Gegenlicht)". "As cores são ações (Taten) e paixões (Leiden) da luz", traduz Marco Giannotti o terceiro parágrafo do Prefácio de 1810 à doutrina goethiana. Sublinha, assim, o lado escuro (de "paixão", de "padecimento", sombrio, que há no pólo antiluz da ação), diluído na tradução inglesa, que recorre à perífrase passive modification (30). No fenômeno cromático, tal como concebido pelo poeta do Fausto, ambos os pólos, co-presentes, se confrontam. Contra esse pano de fundo é que devem ser lidos versos como: "Nun aber bricht aus jenen ewigen Gründen/Ein Flammenübermass" ("Rompe, então, da eterna profundeza/Um plus-de-chamas [...]"); ou ainda: "Do perfúmeo torpor das profundas,/Grotas se avivam cor após cor[...]" ("Farb am Farbe klärt sich los vom Grunde"). 
Calderón pode nutrir a crença barroca em uma "luz branca, única, in mente Dei, decomposta através das multicores lentes humanas" (31); Goethe sabe que o olho que mira uma superfície branca fortemente iluminada ofusca (Farbenlehre, 7). Essa nãoé uma visão mística, mas experimental: não se pode encarar o sol, mas, apenas, o seu reflexo colorido na água de uma cachoeira. Para Calderón, a cruz da Redenção é um novo arco-íris de reconciliação, entre o divino e o humano; ele exprime essa visão cromático-mística através de uma bela imagem paronomástica (em La exaltación de la Cruz, 1644): "Iris de paz que se puso/Entre las iras del cielo/Y los débitos del mundo".

Goethe é um poeta-cientista, como o seu contemporâneo Alexander von Humboldt, autor do monumental Kosmos (1845-62), era um cientista-poeta. O arco variamente colorido que dura e se transforma ao mesmo tempo -“durável câmbio” (Wechseldauer), um oxímoro, figura dialética prestigiada no Barroco - surge logo na cena inicial do Fausto II. Assinala a devolução à vida do pecador, reconfortado pelos espíritos alados. Para o Goethe panteísta e vitalista, cuja crença na imortalidade da enteléquia do homem não passa pelo crivo teológico da salvação, mas pela prova tenazmente humana do fazer incessante; para esse Goethe não se trata aqui do emblema cristão de uma "nova aliança", mas do símbolo irônico (cético?) da transitoriedade da afanosa vida humana, só suscetível de uma sobrevida metamórfica. Das farbige Abglanz, a existência como "reflexo colorido", é também a epifania do instante (Augenblick), daquele instante que o Fausto gostaria de ver perenizado. É esta, aliás, a cifra do pacto ("Verweile doch! du bist so schön!" - "Detém-te agora! és tão belo”).

Para Calderón, "la vida es sueño" (“¿Que es la vida? Unfrenesi./ ¿Que es la vida? Unailusión,/ una sombra, unaficción [...]"), como para Gôngora a edad dorada, a gloria mundi, acaba "en tierra, en humo, en polvo, en sombra, en nada". No Deus cristão e em sua Revelação está a verdade, suma e única, do Barroco espanhol.

Em 1825, ano em que retomou o Fausto,
Goethe começou a esboçar uma “doutrina meteorológica" (Versuch einer Witterungslehre), onde se lê: "A verdade, idêntica ao divino, não se deixa reconhecer por nós diretamente; nós a vislumbramos somente no reflexo (Abglanz), no exemplo, no símbolo, em aparições singulares e afins. Nós a consideramos como uma vida incompreensível e não podemos, no entanto, renunciar ao desejo de compreendê-la. Isso vale para todos os fenômenos do mundo inteligível (des fasslichen Welt)". Só que o conceito goethiano de "divino" não é o cristão, mas envolve uma idéia panteísta de Natureza, regida pela lei da metamorfose contínua. É essa idéia que parece estar por trás do pálio versicolor do reflexo, que nos resguarda do sol ofuscante do vero. Ainda quando essa Natureza possa também ser vista como “órgão do divino" (göttliches Organ). "Somos, enquanto pesquisador da natureza, panteísta; enquanto poeta, politeísta, e, no plano ético, monoteísta" (Maximen und Reflexionen, 807). Eis o retrato interior, complexo e contraditório, de Goethe, em cujo pensamento releva ainda o influxo de Espinoza - o filósofo da célebre fórmula Deus sive Natura - assimilado, porém, de um modo muito pessoal (32).

Assim, apesar do barroquismo de tinturas e traços de estilo, o céu do Segundo Fausto se projeta como palco ascensional, de uma religiosidade não-confessional, laica, paródica, âmbito ornamental para um Triunfo de Vênus (o Eterno-Feminino) e para uma apoteose do fazer humano, movido pela tensão em espiral do empenho (Streben) incessante (33). Nem a gótica rosa mística do Empíreo de Dante, com seu tríplice giro de arco-íris (Paradiso, XXXIII,115-119), nem o domo teologal de Calderón, equilibrado sobre a tensão félivre-arbítrio e chancelado pelo íris da Nova Aliança, se estampam ideologicamente nesse Céu vertiginoso, sem calmaria beatífica, do último Fausto.

Para além do vitral gótico, para além da decoração abarrocada, é o olho crítico da Modernidade que se está abrindo para nós (34).
31 H. Hatzfeld, op. cit. na noto

32 Em Dichtung und Wahrheit, III Goethe fala da forte influência de Espinoza em seu "modo de pensar" (Denkweise), ressa vando, porém: "A paz todoharmonizadora lalles ausgleichende Ruhe) de Espinoza contrasta com o mev esforço todo-dinâmico lalles aufregenden Streben): seu método matemático é o opos to da minha maneira poética de sentir e representar $[\ldots]^{\prime \prime}$

33 Sobre a "tendência à espiral" na ascensão final do Fausto ver Curtius (op. cit. na nota 20) que remonta às teorias goethianas no campo das $\mathrm{c}$ ências naturais. Hatzfeld lop. cit na nota 9/ detém-se sobre a predileção do "homem barroco" pela "forma da espiral" para "dentro" ou para "fora" emblema, esta última, da ressurreição)

34 Quanto à interpretação críticoideológica da "salvação" final ver meu Deus e o Diabo no Fausto de Goethe, São Paulo Perspectiva, 1981, em especial o capítulo "Bufoneria Transcendental: o Riso das Esferas" 


\section{LOCUS AMOENUS}

FAUSTO deitado sobre a relva em flor, exausto, inquieto, tentando dormir.

Crepúsculo.

Ciranda volátil de espíritos, gráceis figuras diminutas.

ARIEL (harpas-eólias guiam-lhe ocanto)

Quando as chuvas primaveram

E suaves bênçãos sobre a terra

Difundem verdes fulgores,

Pequenos elfos magnânimos

Acodem e com brandura

- Seja ele ruim, seja santo -

Socorrem o sem-ventura.

Vós, que circum-voais em torno, etéreos, Desse mortal, elfos heráldeo-aéreos,

Calai no seu peito o atroz conflito,

Sofreai-lhe o remorso, áscua aguçada,

Do horror passado apurai-lhe o espírito.

Quatro, à noite, os turnos da velada:

Pronto os preencha um júbilo irrestrito.

Ao frescor repouse de uma alfombra,

No orvalho do Letes rorejai-o,

Distensos seus membros se reponham,

Da alba da manhã receba o raio.

Perfazei assim a élfea consigna:

Voltai-o à luz santa que o ilumina.

CORO (voz solista, em dueto, ou várias vozes, alternando-se ou em uníssono)

Quando sopra a brisa cálida

Na circum-verde planura,

Do crepúsculo trescalam

Doces aromas, véus-brumas.
Suaves cicios, paz de infância, O coração se inebria.

Sobre o olhar do que descansa

Fechai as portas do dia.

Já baixou a noite escura,

Constela-se estrela a estrela.

Luzes grandes ou fagulhas,

Estas aqui, longe aquelas,

Brilham no lago espelhante,

Rebrilham no céu noturno.

Sela a paz, feliz-fundante,

A pompa do plenilúnio.

Já se exauriram as horas

Solvem-se dor e alegria;

Vês: tua cura não demora;

Crê na luz do novo dia.

Vales, verdor, montes tufam,

Arborescem sombras calmas,

Na dúctil prata que ondula,

Sementes viram searas.

Fruir desejo após desejo?

Ergue os olhos para a aurora.

Envolto num doce harpejo,

Rompe o véu do sono afora.

Não hesites na ousadia,

Curve-se o vulgo e vacile;

Tudo o nobre desafia:

Compreende e firme decide. 
ARIEL

Ouvi! ouvi! Troam as Horas!

O ouvido-espírito agora

Colhe o dia em luz sonora.

Rangem os portais da rocha,

Rola Febo sobre rodas,

Reponta a luz ! Que estampido!

Trom de trombetas e tubas!

O olho ofusca, pasma a escuta,

Que não se ouve o nunca-ouvido.

Deslizai, para a morada

De corolas em grinalda,

Remanso entre pedra e folha;

Se o som vos toca, atordoa-vos.

\section{FAUSTO}

Vívido bate o pulso da vida,

Suave-saudando a etérea alvorada.

Terra, a meus pés, já revivescida,

Noite adentro arfaste, sem parada.

O júbilo toma-me de assalto.

Instas e urges: a meta é firmada -

Sempresforçar-me a um viver mais

[alto.

Abre-se o mundo à luz do arrebol,

Mil sons de vida, um claro coral o

Bosque toma; névoas em lençol

Estriam vales, a luz se afunda,

Caules e ramos viçam do solo,

Do perfúmeo torpor das profundas.

Grotas se avivam, cor após cor,

Tremor perúleo as folhas inunda:

Tenho um paraíso a meu redor.

Olhos ao alto! A montanha altiva gigântea, anuncia a hora maior.

A eterna luz pronto a gratifica,

Só mais tarde sobre nós descende.

Encostas alpinas, verde-esquivas,

De um brilho novo agora

[resplendem,

Que pouco a pouco chega até

[embaixo.

É o sol que surge! A luz que

[desprende

Cega-me e doendo os olhos afasto.

Assim, sempre que a esperança abrasa, Se intenta ao sumo desejo o passo: Portas pleniabertas, portas-asas.

Rompe, então, da eterna profundeza Um plus-de-flamas, que nos arrasta. A tocha queríamos ver acesa Da vida. Um mar de fogo nos colhe. Amor? Ódio? A ardente correnteza Dor e prazer mutua, desconforme.

Baixemos de novo, o olhar ao solo, Que nos véus da infância nos

[recolhe.

Às costas, assim, me fique o sol.

Contemplo, num fascínio crescente, A cascata que estruge entre escolhos, Mil-vezes-mil jorros espalhando

Que espumas no alto ar lançam

[ferventes.

Esplendor! Do vórtice brotando,

Durável câmbio, o arco-íris se

[encurva

- Fixa figura, ou no ar se esgarçandoE esparze um fresco aroma de chuva. Aí se mira e espelha a humana lida. Pensa bem e a compreensão apura: Reflexo colorido, eis a vida. 